\title{
Kinesio tape for edema control after bichectomy: A randomized trial study
}

\author{
Fita kinesio para controle de edema após a bichectomia: Um estudo randomizado \\ Cinta kinesio para el control del edema después de la bicectomía: Un estudio de prueba \\ aleatorizado
}

Received: 04/12/2021 | Reviewed: 04/19/2021 | Accept: 04/22/2021 | Published: 05/09/2021

Gustavo Silva Pelissaro

ORCID: https://orcid.org/0000-0003-3475-6001 Federal University of Mato Grosso do Sul, Brazil E-mail: gustavopelissaro21@hotmail.com

Thábata Flavia Ribeiro Guimarães da Silva

ORCID: https://orcid.org/0000-0002-6547-8836 Federal University of Mato Grosso do Sul, Brazil E-mail: thabata.guimaraes@ufms.br

Aline Bergman de Souza Herculano

ORCID: https://orcid.org/0000-0002-1636-2036 Federal University of Mato Grosso do Sul, Brazil E-mail: aline_herculano@hotmail.com

Muryllo Eduardo Sales dos Santos ORCID: https://orcid.org/0000-0001-8517-4154 Federal University of Mato Grosso do Sul, Brazil

E-mail: muryllosales@gmail.com

Bruno Campidelli Oliveira

ORCID: https://orcid.org/0000-0002-1432-3666 Federal University of Mato Grosso do Sul, Brazil

E-mail: brcampidelli@hotmail.com

Julio Cesar Leite da Silva

ORCID: https://orcid.org/0000-0002-9835-7432 Federal University of Mato Grosso do Sul, Brazil

E-mail: julio.silva@ufms.br

Jefferson José de Carvalho Marion

ORCID: https://orcid.org/0000-0003-4320-2561

Federal University of Mato Grosso do Sul, Brazil

E-mail: jefferson.marion@ufms.br

Leonardo Perez Faverani

ORCID: https://orcid.org/0000-0003-2249-3048

São Paulo State University, Brazil

E-mail: leobucomaxilo@gmail.coma

Gabriel Barbosa Sandim

ORCID: https://orcid.org/0000-0002-8427-1275

Federal University of Mato Grosso do Sul, Brazil

E-mail: gabrielsandim@icloud.com

Albert Schiaveto de Souza

ORCID: https://orcid.org/0000-0003-0017-672X

Federal University of Mato Grosso do Sul, Brazil

E-mail: albert.souza@ufms.br

Ellen Cristina Gaetti Jardim

ORCID: https://orcid.org/0000-0003-2471-465X

Federal University of Mato Grosso do Sul, Brazil E-mail: ellen.jardim@ufms.br

\begin{abstract}
Bichectomy surgery has been increasingly widespread and performed as an aesthetic, functional, or aestheticfunctional treatment. This study aims to describe the surgical technique of bichectomy with the application of the Kinesio tape to verify its effectiveness in controlling edema formation, with the measurement in four postoperative periods. Through a split-mouth, double-blind, randomized study, 13 participants who had an indication for the surgery were selected and divided into two groups - Control Group: bichectomy surgery and cryotherapy for a period of 12 hours, without external application of the Kinesio tape (KT) and Experimental Group: bichectomy surgery, cryotherapy for a period of 12 hours, and application of KT in the outer cheek area of the face, for 2 days. A millimeter measuring tape was used to measure three reference points on the face before and after the surgical procedure (preoperative, 24 hours, 48 hours, and 7 days postoperatively). Quantitative data were subjected to
\end{abstract}


statistical analysis using the Sigma Plot 12.0 program (Exakt graphs and data analysis, San Jose, USA). The comparisons were made according to the edema measurements for the two experimental groups (2 levels: Kinesio tape versus cryotherapy) and the periods of analysis (4 levels: Preoperative, 24 hours, 48 hours and 7 days postoperatively). After obtaining the data, and the statistical analysis, the application of Kinesio Tape proved to be more effective when compared to the use of cryotherapy alone, in the control of postoperative edema in patients who underwent bichectomy surgery. The study contributes to the literature regarding the applicability of the KT and expands the therapeutic possibilities in an aesthetic-functional procedure that is increasingly sought after by patients. Keywords: Athletic tape; Surgery oral; Bichectomy; Fat pad; Fats.

\begin{abstract}
Resumo
A cirurgia de bichectomia tem sido cada vez mais difundida e realizada como tratamento estético, funcional ou estético-funcional. Este estudo tem como objetivo descrever a técnica cirúrgica da bichectomia com a aplicação da fita Kinesio para verificar sua eficácia no controle da formação de edema, com a mensuração em quatro períodos pósoperatórios. Por meio de um estudo duplo-cego, randomizado e duplo-cego, foram selecionados 13 participantes que tinham indicação para a cirurgia e divididos em dois grupos - Grupo Controle: cirurgia de bichectomia e crioterapia por um período de 12 horas, sem aplicação externa do Kinesio fita adesiva (KT) e Grupo Experimental: cirurgia de bichectomia, crioterapia por um período de 12 horas e aplicação de KT na região externa da bochecha, por 2 dias. Uma fita métrica milimetrada foi utilizada para medir três pontos de referência na face antes e após o procedimento cirúrgico (pré-operatório, 24 horas, 48 horas e 7 dias de pós-operatório). Os dados quantitativos foram submetidos à análise estatística por meio do programa Sigma Plot 12.0 (gráficos Exakt e análise de dados, San Jose, EUA). As comparações foram feitas de acordo com as medidas de edema para os dois grupos experimentais (2 níveis: Kinesio tape versus crioterapia) e os períodos de análise (4 níveis: pré-operatório, 24 horas, 48 horas e 7 dias de pósoperatório). Após a obtenção dos dados e análise estatística, a aplicação do Kinesio Tape mostrou-se mais eficaz quando comparada ao uso da crioterapia isolada, no controle do edema pós-operatório em pacientes submetidos à cirurgia de bichectomia. O estudo contribui com a literatura a respeito da aplicabilidade do KT e amplia as possibilidades terapêuticas em um procedimento estético-funcional cada vez mais procurado pelos pacientes.
\end{abstract}

Palavras-chave: Fita atlética; Cirurgia bucal; Bichectomia; Gorduras.

\begin{abstract}
Resumen
La cirugía de bichectomía está cada vez más extendida y se realiza como tratamiento estético, funcional o estéticofuncional. Este estudio tiene como objetivo describir la técnica quirúrgica de la bichectomía con la aplicación de la cinta Kinesio para verificar su efectividad en el control de la formación de edemas, con la medición en cuatro postoperatorios. A través de un estudio aleatorizado, doble ciego, de boca partida, se seleccionaron 13 participantes que tenían una indicación para la cirugía y se dividieron en dos grupos - Grupo Control: cirugía de bichectomía y crioterapia por un período de 12 horas, sin aplicación externa del Kinesio tape (KT) y Grupo Experimental: cirugía de bichectomía, crioterapia por un período de 12 horas y aplicación de KT en la zona externa de la mejilla del rostro, durante 2 días. Se utilizó una cinta métrica milimétrica para medir tres puntos de referencia en el rostro antes y después del procedimiento quirúrgico (preoperatorio, 24 horas, 48 horas y 7 días del postoperatorio). Los datos cuantitativos se sometieron a análisis estadístico utilizando el programa Sigma Plot 12.0 (gráficos y análisis de datos Exakt, San José, EE. UU.). Las comparaciones se realizaron según las medidas de edema para los dos grupos experimentales ( 2 niveles: Kinesio tape versus crioterapia) y los periodos de análisis (4 niveles: Preoperatorio, 24 horas, 48 horas y 7 días del postoperatorio). Tras la obtención de los datos, y el análisis estadístico, la aplicación de Kinesio Tape demostró ser más eficaz en comparación con el uso de crioterapia sola, en el control del edema postoperatorio en pacientes sometidos a cirugía de bichectomía. El estudio aporta a la literatura sobre la aplicabilidad del KT y amplía las posibilidades terapéuticas en un procedimiento estético-funcional cada vez más buscado por los pacientes.
\end{abstract}

Palabras clave: Cinta atlética; Cirugía bucal; Bichectomía; Grasas.

\title{
1. Introduction
}

The buccal fat pad (BFP) or Bichat's fat pad is a relatively spherical mass of fat encapsulated by connective tissue that is located in the masticatory space and is responsible for facilitating the movement of the muscles in its buccal, pterygoid, superficial, and deep temporal extensions (Sicher \& Tandler, 1981).

The surgery to remove part of the Bichat's fat pad is known as Bichectomy and has been performed for some time with functional purposes, including diminishing the interference in chewing and decrease chronic masticatory traumas of the cheek mucosa. These problems are due to the voluminous anatomical structure of BFP, which provides a narrow oral corridor that can be seen through intra-oral clinical examination (Pary et al., 2016). Another purpose of performing bichectomy surgery 
is the use of BFP for the closure of buccal sinus fistulas (Montero et al., 2018). There are also cases of neoplasms or trauma to the jaws, which demand reconstruction, so techniques for performing a graft with the use of BFP are a viable option (Xiao et al., 1999).

However, recently many patients, especially women, have sought surgery for a purely aesthetic purpose. To improve appearance, there are multiple cosmetic surgery procedures for modifying facial features, among which we find bichectomy (International Society of Aesthetic Plastic Surgery, 2016).

The technique aims to remove part of the fat pad from the cheek, looking to provide more defined contours and an inverted triangle aspect of the face, a world standard for female beauty (Stevão, 2015). It differs from adipose tissue in other regions because it is never consumed, even in cases of exaggerated weight loss (Madeira, 2011). This surgery is indicated for aesthetic, functional, or aesthetic-functional purposes. Nevertheless, a thorough analysis of the patient is essential to suggest the procedure, taking into account the general state of health, which must be in balance. Some contraindications are patients with local infections; heart diseases; immunosuppression; coagulopathy; uncontrolled diabetes and uncontrolled hypertension (Stuzin et al., 1990).

The professional must know the anatomical structures for a correct evaluation, indication, and execution of the procedure. Bichectomy is a relatively simple procedure, performed with local anesthetic (Matarasso, 2006).

As adjunctive therapy, the Kinesio taping (KT) was developed in the 1970s as described by Kase et al., in 2003. This tape, which has no latex in its composition, has acrylic adhesiveness and its activation occurs by body temperature. It is composed of elastic polymer threads wrapped by cotton fibers. Besides the improvement in blood flow, the tape also decreases the retention of lymphatic liquid and bruises. When providing space, fluids are encouraged to move from areas of higher pressure to the area of lower pressure, guided by the tape in the desired direction of drainage.

The literature is scarce and there is no significant clinical and practical experience with the use of KT in the postoperative period of oral surgeries. Also, the literature shows preliminary positive results in the use of the tape in the postoperative period for the treatment of edema after extraction of third molars, accelerating the drainage of the tissue reaction, or even in the containment of bruises (Rocha Heras et al., 2020; Magistro, 2015).

All in all, the objective is to assess whether the extraoral application of KT after bichectomy surgery may have a favorable impact on post-surgical edema, providing a better quality of life to the patient during the first week after surgery.

\section{Methodology}

This split-mouth, double-blind, randomized study (Köche, 2011; Magistro, 2015) was submitted to analysis by the Research Ethics Committee of the Federal University of Mato Grosso do Sul, approved under appraisal number 4.465.331.

\section{Discomfort and risks}

The risks related to the research were paresthesia due to the use of local anesthetics; abundant bleeding and poor healing resulting from the surgery; formation of transient edema; transient trismus, and discomfort with postoperative pain. All risks are temporary and inherent in any intraoral surgical procedure. Participants may also experience an allergic reaction, aesthetic or functional discomfort with the application of the tape. To minimize such risks, all complications, if they occurred, were attended to promptly and remedied by the researcher in charge with no cost to the participant.

\section{Advantages}

Direct benefits to participants are aesthetic, functional, or aesthetic-functional. The partial removal of Bichat's fat pad for aesthetic purposes aims to reduce the appearance of a rounded face, providing better facial harmony. In patients who have a 
narrow buccal corridor space and therefore bite the cheek mucosa causing traumatic injuries, the functional procedure will reduce these traumatic injuries, preventing wounds or ulcerations. The KT will promote control of the acute phase of edema, reducing the need for medicines, providing a post-operative period with a greater quality of life and less morbidity.

\section{Experimental design}

This study included 13 participants with ASA I classification (American Society of Anesthesiologists), duly regulated by the Unified Health System (SUS, in Portuguese) and treated at the outpatient clinic of the Oral and Maxillofacial Surgery of the University Hospital "Maria Aparecida Pedrossian" - (HUMAP), with a history of chronic trauma in the jugal mucosa, bilaterally, and that could be benefited by the bichectomy.

All the participants in this group underwent two simultaneous intraoral surgical procedures to remove the BFP. Each participant was his/her control, i.e. each patient had one side of the face using the Kinesio tape (experimental group) and the other side that did not receive the Kinesio tape (control group). The face side (left or right) that would receive the Kinesio tape was determined by lot. Also, on both sides, cryotherapy was prescribed in the postoperative period. A researcher who did not perform the surgeries carried out this design, and the researcher responsible for the surgery did not know which side of the face was the control group or the experimental group. A professional that did not know of the protocols used, characterizing a double-blind study, also carried out the analysis of the results.

The same pharmacological protocol before and after surgery was used for all participants. Thus, before surgery, an 8 $\mathrm{mg}$ dexamethasone tablet was prescribed one hour before the intervention. For the post-surgical period, 500mg of amoxicillin $8 / 8 \mathrm{~h}$ for 07 days, ibuprofen $600 \mathrm{mg}$ 12/12h for 03 days, and dipyrone $500 \mathrm{mg} 6 / 6 \mathrm{~h}$ for 02 days were prescribed. It was instructed to all participants to apply ice packs during the first 12 hours after surgery on both sides.

The treatment protocols for each side of the face were as follows:

Experimental: Bichectomy surgery, cryotherapy for a period of 12 hours, and application of KT in the outer cheek area of the face for a period of 2 days.

Control: Bichectomy surgery followed by cryotherapy for a period of 12 hours, without external application of KT.

\section{The surgical technique to remove the Bichat's fat pad}

The same operator performed the bichectomy surgeries during the mornings. Extraoral antisepsis was performed with a 2\% aqueous solution of chlorhexidine digluconate (Riohex® - Rioquimica São José do Rio Preto, Brazil), and the intraoral was performed by means of a vigorous rinse, for one minute, with an aqueous solution of $0.12 \%$ chlorhexidine digluconate mouthwash without alcohol (Colgate PerioGard®, Colgate-Palmolive Company, New York, USA).

Anesthesia of the posterior and middle superior alveolar nerves was performed using a self-aspirating dental cartridge syringe (Quinelato Surgical Instruments, Rio Claro, Brazil) with a 27 gauge disposable long needle (Injex Surgical Industries, Ourinhos, Brazil). For anesthesia, 4\% articaine hydrochloride solution with epinephrine 1:100,000 (Articine, DFL, Taquara, Brazil) was used, and the maximum dose $(7 \mathrm{mg} / \mathrm{kg}$ ) was calculated according to the weight of each participant (MALAMED, 2013).

After intraoral and extraoral antisepsis, the sterile field was placed in position, and anesthesia of the posterior and middle superior alveolar nerve was performed. A horizontal incision of $1 \mathrm{~cm}$, with a No. 15 surgical blade (Solidorß Lamedid Commercial and Services, Barueri, Brazil), was made in the maxillary vestibule in the middle of the zygomatic pillar continuing to the posterior area. After that, the muscles were divulsed to access the fat pad, and then 2/3 from BFP was removed. After partial BFP removal, copious irrigation with $0.9 \%$ saline (Sorimax ${ }^{\circledR}$, Farmax, Divinópolis, Brazil) was performed. The removed BFP content was measured in $\mathrm{mL}$ using a syringe (Injex Surgical Industries, Ourinhos, Brazil). 
The closing was performed with a 4-0 Nylon suture (Procare, Rio de Janeiro, Brazil) with a suture on each incision end with a free median portion for lymph drainage. After the surgical procedure, the face was cleaned with Isopropyl Alcohol $70 \%$ (Ciclo Farma, Serrana, Brazil), and the KT was applied to compress dead space.

\section{Kinesio Taping application technique}

The application of KT was adapted from the one described by Magistro (2015). The procedure for applying the KT was performed by the same examiner with expertise in using this material. The skin was cleaned with facial gel (Normaderm ${ }^{\circledR}$, Vichy Laboratoires, Vichy, France) to eliminate water and oil before KT application. A skin marker pen (DERMarker, Viscot Medical, East Hanover, USA) was used to make three points as follows: Point A on the tragus; point B at the labial commissure, and point $\mathrm{C}$ at the mental protuberance, being compatible with face midline. To measure the points, the patient was in a natural, relaxed position.

The tape was cut at its end to obtain rounded edges. Its length was individualized for each patient. The tape length was based on the marking points: Points A to B and points A to C, with a $20 \%$ decrease in the actual length between the points. The width was $3 \mathrm{~cm}$ on both tapes. The first tape was applied with slight tension until it touched the points $\mathrm{A}$ and $\mathrm{B}$. In the same way, the other tape was applied, however, joining points $\mathrm{A}$ and $\mathrm{C}$. The edge of the second tape that came out of point A was positioned immediately below the first tape.

\section{Postoperative procedures}

After the end of the surgical procedure, the participants were instructed to eat a liquid, pasty, high-protein, and cold diet, in the first 48 postoperative hours. The team advised patients to apply ice packs during the first 12 hours after surgery on both sides. Besides other general instructions, such as not making physical efforts, avoid exposure to the sun, and not use any mouthwash in the first 48 hours.

A third researcher measured the edema at 24 and 48 hours after surgery, using a millimeter measuring tape.

\section{Inclusion criteria}

Fall under the ASA I (American Society of Anesthesiologists) classification criteria, that is, healthy, without physiological, biochemical, or psychiatric disorders;

Present indication for bilateral bichectomy after an ultrasound exam and clinical examination.

\section{Exclusion criteria}

Be allergic to any of the medications used in this study;

Be between 18 and 26 years old;

Not attending the postoperative period;

Not having a record of the National Health System (SUS).

\section{Data collection}

\section{Preoperative information}

A millimeter measuring tape was used to measure three reference points on the face before the surgical procedure. In order to ensure that the reference points were reliable for measurement during the entire 7-day period, the participants were marked with henna ink, and they were instructed not to remove the markings, which would be renewed after each measurement (Souza et al., 2011). 
For measurement, the technique described by Amin and Laskin (1983) with slight modification was used: 1) lateral corner of the eye to the jaw angle (Vertical Distance - VD); 2) tragus to the labial commissure (Horizontal Distance to Commissure - HDC); 3) ear lobe to the labial commissure (Horizontal Distance to Lobe - HDL).

The measurements were added and divided by three [(VD+HDC+HDL)/3] to provide a preoperative facial mean, which was later compared with the facial mean after the surgical procedure. These measurements were taken four times, the first before the surgical procedure and the others after 24 hours, 48 hours, and 7 days. These obtained data were inserted into an Excel sheet (Microsoft Corporation, Rendmond, USA).

\section{Postoperative information}

A millimeter measuring tape was used to measure the three points described previously, which were added up and divided by three, providing a facial mean, to verify the size of the edema, in case it happened. These measures were taken 24 hours, 48 hours, and 7 days after surgery. The data obtained were entered into an Excel table.

\section{Evaluation criteria}

The edema was measured by a third researcher (Table 1). For this purpose, a millimeter measuring tape was used to assess the three measures as a reference:

Facial measurements were calculated as follows: $[(\mathrm{VD}+\mathrm{HDC}+\mathrm{HDL}) / 3]=$ edema size .

Table 1: Data Collection Instrument. Edema evaluation according to the periods.

\begin{tabular}{|c|c|c|c|c|c|c|c|}
\hline \multirow[t]{2}{*}{ PERIOD } & \multirow[t]{2}{*}{ GROUP } & \multicolumn{2}{|c|}{ EDEMA } & \multicolumn{3}{|c|}{$\begin{array}{c}\text { EDEMA MEASUREMENT } \\
{[(\mathrm{VD}+\mathrm{HDC}+\mathrm{HDL}) / 3]}\end{array}$} & \multirow[t]{2}{*}{ EDEMA SIZE } \\
\hline & & ABSENT & PRESENT & VD & HDC & HDL & \\
\hline \multirow[t]{3}{*}{ Preoperative } & Control & & & & & & \\
\hline & Experimental & & & & & & \\
\hline & & & & & & & - \\
\hline \multirow{3}{*}{$\begin{array}{l}24 \text { hours } \\
\text { postoperatively }\end{array}$} & Control & & & & & & \\
\hline & Experimental & & & & & & \\
\hline & & & & & & & - \\
\hline \multirow{3}{*}{$\begin{array}{l}48 \text { hours } \\
\text { postoperatively }\end{array}$} & Control & & & & & & \\
\hline & Experimental & & & & & & \\
\hline & & & & & & & - \\
\hline \multirow{2}{*}{$\begin{array}{l}7 \text { days } \\
\text { postoperatively }\end{array}$} & Control & & & & & & \\
\hline & Experimental & & & & & & \\
\hline
\end{tabular}

Source: Authors (2021).

Vertical Distance (VD) corresponding to the lateral corner of the eye to the jaw angle. Horizontal Distance to Commissure (HDC), being tragus to the labial commissure. And finally, Horizontal Distance to the ear lobe (HDL) being the ear lobe to the labial commissure.

\section{Statistical analysis}

The data were initially submitted to the Shapiro-Wilk test, which showed homogeneity ( $p>0.05$ ). Then, they were compared by the two-way ANOVA with repeated measures (1st factor: experimental group ( 2 levels: kinesio vs cryotherapy); 2nd factor: period analysis: preoperative, 24, 48 hours, and 7 days), and for interactions with a $p<0.05$ the Holm-Sidak posttest was applied. The significance level of $5 \%$ was considered for all tests, which were performed using the statistical program SigmaPlot 12.0 (Exakt Graph and Data Analysis, San Jose, USA). 


\section{Results and Discussion}

In the statistical interactions of the two-way ANOVA with repeated measures, all interactions showed significant changes ( $\mathrm{p}<0.001$ ). For all postoperative periods, the Kinesio tape was able to reduce the edema, compared to the values of the cryotherapy group, which always presented the highest values, including 7 days after the surgery $(\mathrm{p}<0.05)$. In the intragroup comparison, cryotherapy was only able to reduce the edema compared to the preoperative period at 7 days ( $\mathrm{p}<0.05$ ), while the Kinesio tape already showed edema control in the 24 hours with lower values, even when compared to preoperative $(\mathrm{p}<0.05)$ (Figure 1).

Figure 1 - Representative graph of the measures mean and standard deviation of the edema measured in the preoperative period, 24, 48 hours, and 7 days after the bichectomy surgery, with therapy to contain the edema using the Kinesio tape or cryotherapy.

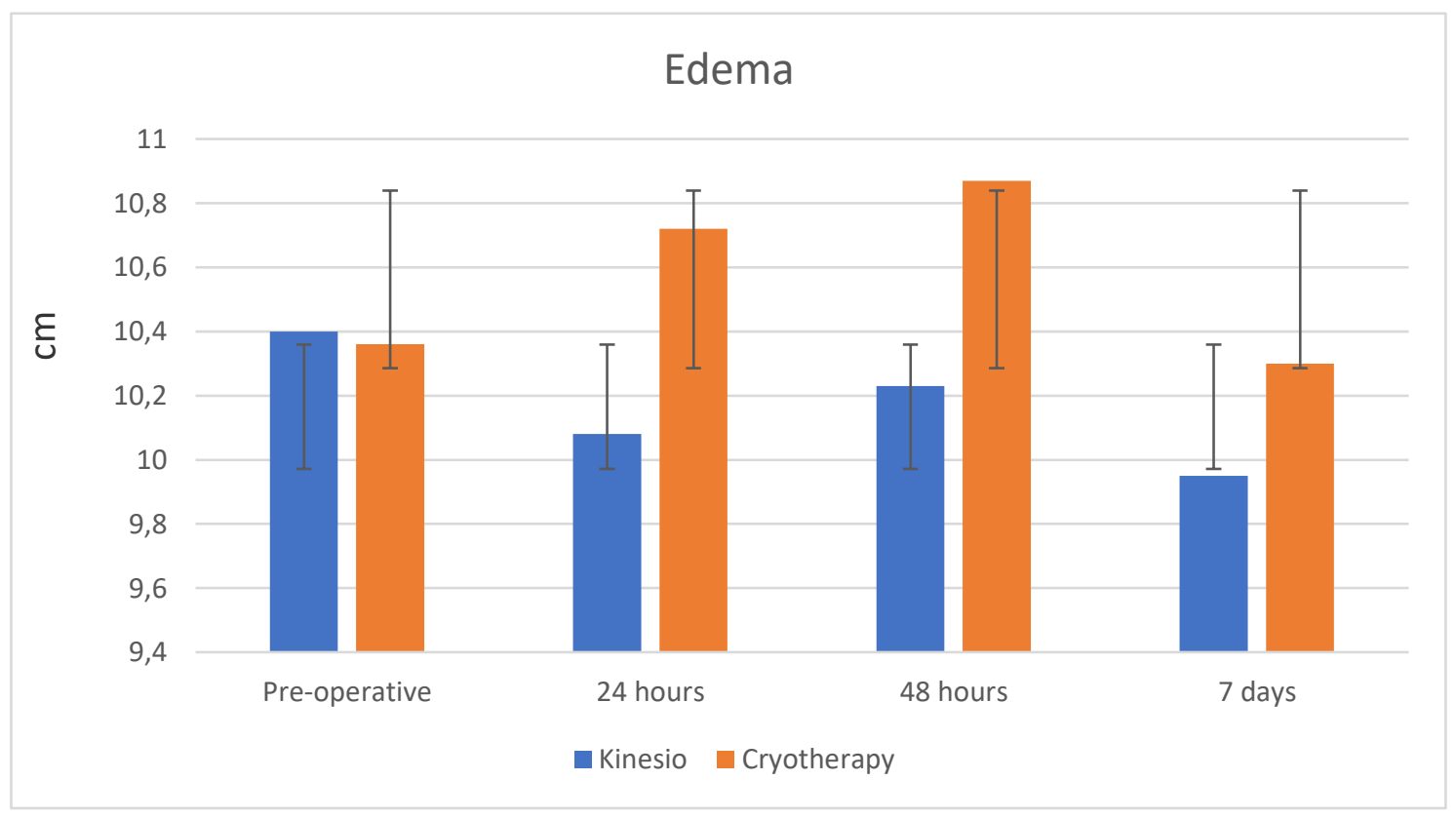

Source: Authors (2021).

Bichectomy is one of the oral procedures that has been gaining more and more supporters. Like other oral procedures, surgery to remove BFP can generate pain, edema, and limited mouth opening in the postoperative period. Consequently, surgeons seek alternatives to minimize post-surgical complications leading to the control of these symptoms, which shows the importance of the results listed.

Even though the presence of edema and painful symptoms can be mostly controlled by medication, it is strategic to use supporting resources to contribute to patients well being. The situations going beyond the usual postoperative control for oral procedures can generate complications that range from the need for outpatient care or even hospitalization in cases of potential severity (Alves Júnior et al., 2020).

The literature shows that the Kinesio tape is effective in the reduction of edema, pain, and trismus after third molars extractions. Thus, although there are no articles in quantity to endorse the KT effectiveness in bichectomy surgeries, the result of this research is in line with what was observed for extractions. KT usage proved to be effective in the containment and regression of post-surgical edema in the three periods of analysis after bichectomy.

The edema was much more pronounced in the group using cryotherapy only, mainly in the first 24 hours after surgical procedure, as well as on the second postoperative day, known as the peak of the edema. Thereby, KT was able to have more 
influence on its containment than the isolated use of cryotherapy.

Cryotherapy slows down cell metabolism and decelerates normal chemical reactions. Also, it contributes to blood vessel contraction and a decrease in nerve conduction, nerve impulse, and inflammatory process. On the other hand, previous works demonstrate that the Kinesio tape can improve blood and lymph flow, reducing fluid retention (Kase et al., 2003) and helping pain control (Tozzi et al., 2016). So, unlike thermotherapy, the increase in vascular circulation promoted by KT is strongly correlated with better pain management and postoperative symptomatology, contributing to a better post-surgical result.

Although this work has not directly evaluated pain management, better pain control using KT can be inferred since extensive edema associated with an evident inflammatory condition has a strong correlation with the increase of painful symptoms (da Rocha Heras et al., 2020; Ristow et al., 2014). Such evidence can be observed comparing 24 and 48 hours after the bichectomy surgery. A relevant period considering the maximum edema in oral surgeries is seen mainly around the second postoperative day. Thereby, due to the immediate impact edema has on the patient's quality of life, the results suggest that KT is a valuable strategy to promote the least edema and consequently less painful sensitivity to the patient.

\section{Conclusion}

All in all, the use of the Kinesio tape proved to be effective in controlling edema after bichectomy surgeries at all periods analyzed, establishing it as a worthwhile alternative option for symptom control. More researches on the bichectomy are needed in order to expand knowledge about the same.

\section{Acknowledgments}

We thank Programa Institucional de Bolsas de Iniciação Científica (PIBIC UFMS), Conselho Nacional de Desenvolvimento Científico e Tecnológico (CNPq) and Coordenação de Aperfeiçoamento de Pessoal de Nível Superior (CAPES) for supporting this work.

\section{References}

Alves Júnior, L. C., Sousa, B. B., Zacarias, V. L. B., \& Germano, A. R. (2020). Oral lipectomy: mediate surgical complication report. Research, Society and Development, 9(10): e4949108921.

Amin, M. M., \& Laskin, D. M. (1983). Prophylactic use of indomethacin for prevention of postsurgical complications after removal of impacted third molars. Oral Surg. Oral Med. Oral Pathol, 55: 448-451.

International Society of Aesthetic Plastic Surgery. Estudo internacional em estética/cosmética Procedimentos realizados em 2016. http://www.isaps.org/Media/Default/Current\%20News/GlobalStatistics2016.pdf

Kase, K., Wallis, J., \& Kase, T. (2003). Clinical therapeutic applications of the Kinesio Taping Method. (2a ed.), Tokyo: Ken Ikai. p. 19-39.

Khiabani, K., Keyhan, S.O., Varedi, P., Hemmat, S., Razmdideh, R., Hoseini, E. (2014). Buccal fat pad lifting: an alternative open technique for malar augmentation. J Oral Maxillofac Surg, 72(2): 1-15.

Köche, J. C. (2011). Fundamentos de metodologia científica: teoria da ciência e iniciação à pesquisa. Edição digital. Vozes.

Madeira, M. C. (2001). Anatomia da Face: Bases Anátomo-funcionais para a prática odontológica. (3a.ed.), Sarvier. p. 84- 85.

Magistro, M. (2015). Utilizzo di una metodica innovativa e non invasiva per controllare la sintomatologia infiammatoria durante il decorso postoperatorio in interventi di implantologia [Tese de doutorado] [internet] Milão: Università Degli Studi di Milano.

Malamed, S. F. (2013). Manual de Anestesia Local. (6a ed.).

Matarasso, A. (2006). Managing the buccal fat pad. Aesthetic Surg J, 26: 330-36.

Montero, J. F., de Souza, H. C., Martins, M. S., Oliveira, M. N., Benfatti, C. A., \& Souza Magini, R. (2018). Versatility and Importance of Bichat's Fat Pad in Dentistry: Case Reports of Its Use in Occlusal Trauma. JCDP, 19(7), 888-894. 
Research, Society and Development, v. 10, n. 5, e33610514983, 2021

(CC BY 4.0) | ISSN 2525-3409 | DOI: http://dx.doi.org/10.33448/rsd-v10i5.14983

Pary, A., Pitta, M., Silvares, M. G., \& Lurentt, K. (2016). A cirurgia estética da face deve ser área de atuação do cirurgião bucomaxilofacial? J Braz College Oral Maxillofac Surg, 2(3): 39-46.

Ristow, O., Pautke, C., Kehl, V., Koerdt, S., Hahnefeld, L., \& Hohlweg-Majert, B. (2014). Physiother Theory Pract, 30(6): 390-398.

Rocha Heras, A. C., Oliveira, D. M., Guskuma, M. H., Araújo, M. C., Fernandes, K. B., Silva, R. A. Junior, et al. (2019). Kinesio taping use to reduce pain and edema after third molar extraction surgery: A randomized controlled split-mouth study. J Craniomaxillofac Surg, 48(2): 127-31.

Seymour, R., Meechan, J., \& Blair, G. (1985). An investigation into post-operative pain after third molar surgery under local analgesia. Br J Oral Maxillofac Surg, 23:410-8.

Sicher, H., \& Tandler, J. (1981). Anatomia para dentistas. Atheneu. p. 99.

Stevão, E. L. L. (2015). Bichectomy ou Bichatectomy - A small and simple intraoral surgical procedure with great facial results. Adv Dent \& Oral Heath, 1(1): 001-04.

Stuzin, J. M., Wagstrom, L., Kawamoto, K., Baker, T. J., \& Wolfe, S. A. (1990). The anatomy and clinical application of the buccal fat pad. Plast Reconstr Surg, 85: 29-37.

Tatli, U., Benliday, I. C., Salimo, F., \& Guzel, R. (2020). Effectiveness of kinesio taping on postoperative morbidity after impacted mandibular third molar surgery: a prospective, randomized, place'bo-controlled clinical study. J Appl Oral Sci, 28: e20200159.

Tozzi, U., Santagata, M., Sellitto, A., \& Tartaro, G. P. (2020). Influence of Kinesiologic Tape on Post-operative Swelling After Orthognathic Surgery. J Maxillofac. Oral Surg, 15(1): 52-58.

Xiao, H., Bayramiçli, M., \& Jackson, I. T. (1999). Volumetric analysis of the buccal fat pad. European J Plastic Surg, 22(4):177-180. 